\title{
IAMJ
}

INTERNATIONAL

AYURVEDIC

MEDICAL JOURNAL

\section{MANAGEMENT OF THROMBOANGIITIS OBLITERANS - A CASE REPORT}

\author{
Vishal Chougule $^{1}$, Shailesh Shetty ${ }^{2}$
}

${ }^{1}$ Professor \& HOD Department of Panchakarma, ${ }^{2}$ Assistant Professor, Department of Panchakarma Dr. N. A Magadum Ayurvedic Medical College and Research Center, Ankali, Belagavi, Karnataka, India

Corresponding Author: drvishalchougule@gmail.com

https://doi.org/10.46607/iamj3909072021

(Published Online: July 2021)

Open Access

(C) International Ayurvedic Medical Journal, India 2021

Article Received: 09/06/2021 - Peer Reviewed: 13/06/2021 - Accepted for Publication: 18/06/2021

\section{Check for updates}

\begin{abstract}
Thromboangitis obliterans (TAOs) is a rare disease affecting arteries and veins of the upper and lower limbs. The condition has a strong association with the use of tobacco. Thromboangitis obliterans also known as Buerger's disease is found in the age group between 40 to 45 years, and men are most prone to get affected. The present case is a male aged 65 years complaining of a wound on the heel on the right foot, associated with pain, discharge, slough, foul smell, edema and discolouration of the skin for which he visited our hospital, the patient was previously diagnosed as TAO, considering his clinical features at the time of admission, an intervention was planned based on the treatment principle of Dusta Vrana like Virechana, Basti and Raktamokshana. There was complete healing of the wound at the end of the treatment with no signs of recurrence during the follow-up suggesting the need for Shodhana in the effective management of TAO.
\end{abstract}

Keywords: Dushta Vrana, Thromboangiitis Obliterans, Ayurveda, Panchakarma, Shodhana, Case report

\section{INTRODUCTION}

As the sciences have advanced, newer remedies are tried out for speedy recovery, but the oldest remedies still lead the race. Wound healing procedures described by sushruta still hold their place today. The faster the wound healing, the faster is the recovery of the patient enabling him to resume his daily routine. These included various purification therapies (shodhana) and local applications (ropana) of natural re- 
sources, which are available very easily and heal the wound faster without any sepsis. One of such purification therapies explained by Sushrutas Virechana to eliminate the pravrudha doshas out from the body, particularly in vata-pitta pradoshaj dushtavrana along with basti and raktamokshana.

\section{Patient Information:}

\section{A brief history of the patient}

A $65 \mathrm{yr}$ old male presented with the complaint of a wound on the heel of the right foot, associated with pain, discharge, slough, foul smell, edema and discolouration of the skin near the wound for 1year 6 months. Previously patient was alright, and then while working in the factory he was feeling numbness at the fingers of the right lower limb and produced swelling with pain. After few days, the swelling burst due to suppuration and resulted in the wound. The wound was treated with a conventional antibiotic, ointment by a local doctor but the wound failed to respond, presumably because of wound contamination and movement of the part. Treatment continued for a period of about 6 to 7 months, but the wound became worst and after that, he got admitted to hospital for the wound management and after the venous colour doppler he has diagnosed as TAO (thromboangiitisobliterans) but the condition was not improved, so he visited us.

\section{History:}

There is no history of DM, HTN and on local examination, there is no varicosity in the affected limb. His family history was not suggestive of anything specific.

\section{Drug History:}

Betadine Liq. e/a, oflox 400 1-0-1 $* 5$ days, Dolokind $100 *$ S.O.S

\section{Clinical findings}

The local examination revealed an open oval-shaped wound on the heel of the right foot (approximately 2 $\mathrm{cm}$ ) associated with pain, discharge etc. There was tenderness nearby the wound.

\section{Investigation:}

Routine haematology (Hb, TC, DC, ESR, and RBS) and urine investigations were within normal limits.

\section{Treatment given.}

Table 1: Treatment Plan

\begin{tabular}{|l|l|l|}
\hline Treatment & Yog & Duration \\
\hline 1. Vranaprakshalan & Triphalakwath & 3 months \\
\hline 2.Vrana ropan & Jatyadi taila & 3 months \\
\hline 3.Virechan karma & Deepan pachan - Arogyavardhini vati & 7 days \\
\hline Snehapan - & Guggulutiktakghrit & 5 days \\
\hline Snehan + swedan & Murchit taila Dashamoolkwath & 4 days \\
\hline Virechanyog- & Trivruttalehya +Triphalakwath & \\
\hline 4.Basti & Guduchiksheerbasti & 15 days \\
\hline 5.Rakatmokshan & Jaloukavacharan & 5 settings \\
\hline 6.Shamanoshadhis & Kaishorguggulu; Triphalaguggulu; Tapyadilauha; & 3 months \\
\hline & Mahatiktakkashya; Guggulutiktakghrit & \\
\hline
\end{tabular}

As the experts recommend virechana in wounds vitiated by predominant vata and pitta dosha and which are chronic. So, here virechana selected to eliminate these pravruddha doshas out from the body, jaloukavcharan for to eliminate raktadusti and guduchyadi ksheer basti to pacify vatadi dosha. After cleaning the wound with triphala kwath and jatyadi taila applied in adequate quantity with the help of the spatula and the wound was covered with sterile gauze and a loose bandage.

\section{OBSERVATION AND RESULTS:}

The clinical features of dushtavrana were improved at the end of virechan and granulation started after Raktamokshan, Basti and the wound was healed completely leaving only a minimal scar Fig 5. With a follow up for one year, the patient has shown no signs of recurrence. 


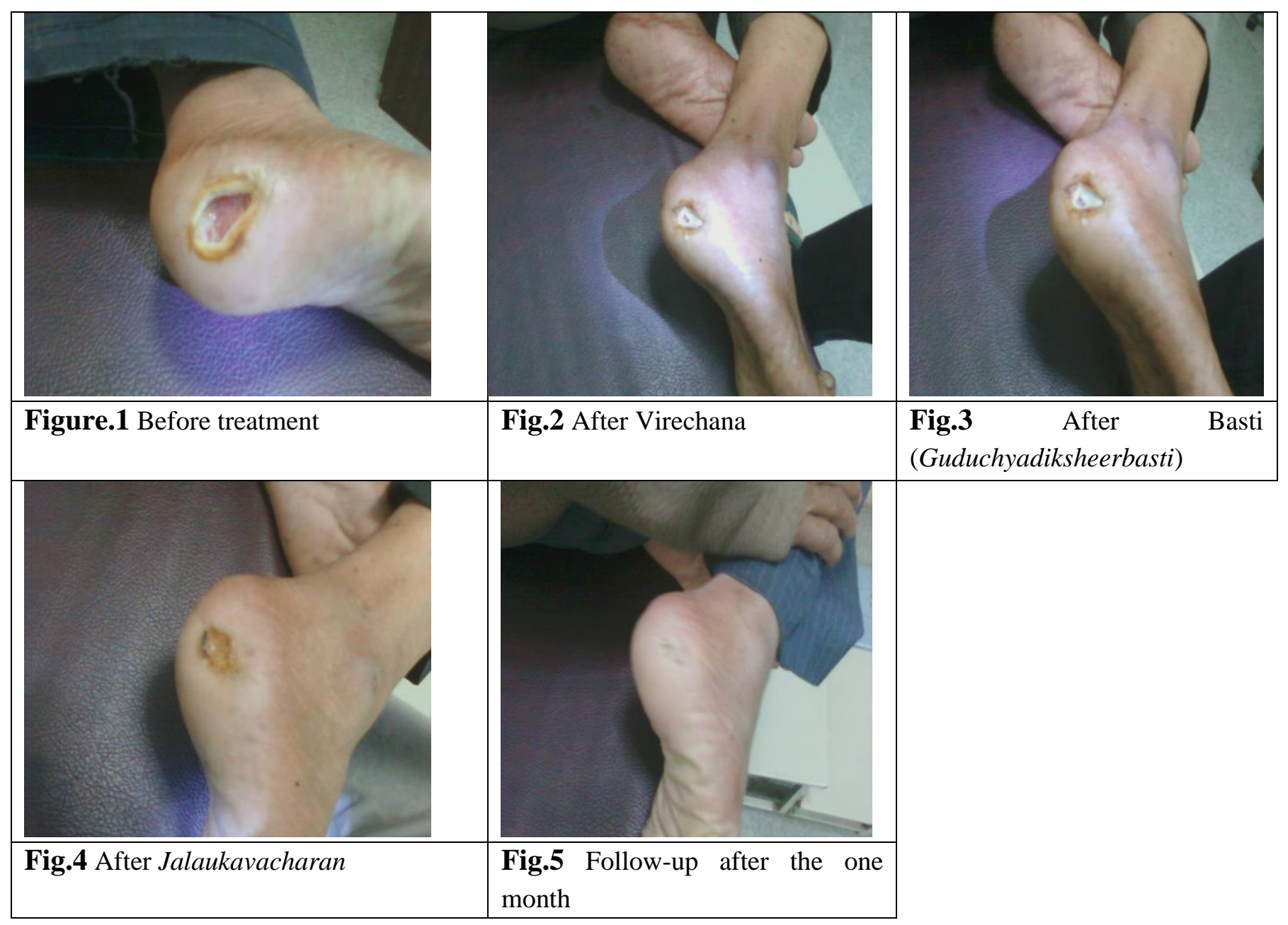

\section{DISCUSSION}

Susrutha has described the sixty manifold measures (shastivranaupokarmas) $^{1}$ for wound management from its manifestation to the normal rehabilitation of the hair in the scar. And given foremost to, measures like shodhana and ropana in the management of dusthavrana.

Shodhana can be divided into two types: Internal purification (Abhyantarashodhana), Virechan, Raktamokshan and Basti Karma. External purification (Bahyashodhana), Vranaprakshalan and Vranaropan

- Effect of treatment on varna: Change in colour occurred when dushtavranaget converted into shuddha, which was due to the elimination of doshasout from the body.

- Effect of treatment on sraava: The vitiated pitta is responsible for pakakriya, which by biting the raktaforms pooya. The virechana karma helps in the elimination of vitiated pitta from the body and thus controls upon the Pakakriya, which results in the subsidence of sraava. Absence of Sraava (pus) suggestive of the wound is devoid of infection.

- Effect of treatment on vedana: Vedana pradurabhava in dushta vranais the effect of vitiated vata and pitta doshaon the dhatus like rasa, rakta, mamsaetc. Virechana controls the vitiated vata and pitta. Thus, Virechana therapy not only expels the vitiated pitta dosha but also controls the vitiated the vata dosha by removing margaavarodha.

- Effect of treatment on Granulation tissue: Virechan not only eliminates the doshasbut also helps in removing the impurities of jeevashonita, 
dhatus, indriyasandoja, which results in the formation of healthy granulation tissue.

- Effect of treatment on Size of the wound: The virechana undertaken has helped for proper perfusion (Circulation) to the wound and hence accelerated the wound healing process.

The treatment of virechana along with the local application of jatyadi taila ${ }^{2}$ resulted in marked improvement in varna, vedana, sraava, size of the wound and granulation tissue.

\section{CONCLUSION}

Virechana and Basti act through systemic correction and regulation of Doshas, which involves in the formation of Dushtavrana., Raktamokshan improves the potency of an individual cell of the body, increases the sensitivity of cells in the wound site towards the local application i.e. Vranashodhan and Vranropan taila, hence accelerates the wound healing. It has fast wound healing properties. The combination of Shodhana and Ropana resulted in proper and early healing of the dushta vrana.

\section{REFERENCES}

1. Susruta. Susruta Samhita. Nibandhasangraha commentary by Sri Dalhanacharya, edited by Vaidya Jadavji Trikamji Acharya. Chaukhamba Sanskrit Sansthan, Varanasi; reprint-2017. p.397

2. Kaviraja Ambikadattashastri. Bhaishajya Ratnavali. Chaukhamba Prakashan, Varanasi; reprint-2017. p.175

\section{Source of Support: Nil \\ Conflict of Interest: None Declared}

How to cite this URL: Vishal Chougule \& Shailesh Shetty: Management Of Thromboangiitis Obliterans - A Case Report. International Ayurvedic Medical Journal \{online\} 2021 \{cited July 2021\} Available from: http://www.iamj.in/posts/images/upload/1560_1563.pdf 